\title{
STUDENTS' AMBIGUITY IN WRITING AN ESSAY
}

\author{
Rulik Setiani *) \\ rulik.setiani@yahoo.com \\ Pendidikan Bahasa Inggris \\ STKIP Muhammadiyah Kotabumi
}

\begin{abstract}
Abstrak
Menulis merupakan salah satu kemampuan berbahasa yang harus dikuasai oleh siswa. Dengan menulis siswa dapat menuangkan ide, pendapat, dan pikiranya secara tertulis. Untuk dapat menulis esai dengan baik, hendaknya siswa/mahasiswa menguasai beberapa komponen bahasa yang lain, diantaranya meguasai struktur kalimat (grammar) dengan benar, menguasai dan memiliki perbendaharaan kata yang cukup, dan penggunaan tata ejaan serta tanda baca yang tepat. Sedangkan dalam menulis esai, juga harus memperhatikan tiga bagian esai yaitu diawali dengan paragraf pembuka, kemudian paragraf isi, dan diakhiri dengan paragraf penutup. Namun untuk menulis esai dengan susunan yang baik dan tepat (well organized) tidaklah mudah bagi siswa/mahasiswa. Pada kenyataanya kalimat yang mereka susun masih sering mengalami makna ganda atau ambigu. Ambigu dapat terjadi dalam tiga bentuk diantaranya ambigu dalam bentuk bunyi (Phonological ambiguity), ambigu dalam kata (lexical ambiguity), dan ambigu dalam susunan kalimat (grammatical ambiguity).
\end{abstract}

Key Words: Writing, Essay, Ambiguity

\section{Introduction}

Writing is one of the skills in English that should be mastered by the students. Generally, writing is a way in sending the message from the writer to the reader. To write appropriately, it is needed for the students to master other English components, such as grammar, vocabulary, and spelling and punctuation. They must be able to organize the ideas to construct the sentences appropriately. Beside that, in writing, a writer should interpret his or her thought into language which can be understood by the readers without any further help from the writer. It is clear that writing is much more than arranging the word into a paper, it also requires ideas that should be transferred into written from that make it becomes concrete and visible to write well, so that the readers can explore what they have read. Besides, to write well the students are expected to be able to present their ideas in written well. Weisman (2007:106) suggests, "Writing can be the most challenging of the four domains of language." Writing takes more effort to produce than to receive. Writing is considered as a productive skill, it aims at assisting students in expressing their written idea. 
Essay writing is one of the compulsory subjects that must be mastered by students of English language education study program because by writing an essay they can express their ideas or thoughts in written form, while good writing is written that can provide information to the reader clearly. Writing is one of the language activities that are productive and expressive. Students generally assume that writing is very difficult. It was faced by many students in primary and secondary education, students in universities also face the difficulties of writing. The result of the complaint eventually became a public opinion, that writing was difficult (Sukirman in Khuzaenah and Herawati, 2017:150). To direct students to be able to write scientific papers, it must be done in some stages. When talking about courses writing specifically writing essay in English is not easy, many components of writing an essay that must be mastered by students included grammar, vocabulary, spelling, punctuation and capitalization. But sometimes they have they have some difficulties when they write, such as their writing is ambiguous.

Ambiguity is a phenomenon which deserves a careful observation. Ambiguity needs to be thought deeply, to be exposed and eliminated. That is because students often use words that have more than one meaning, but do not include supporting sentences to show the meaning of the word. And sometimes, students wrote ambiguous sentence caused by anaphora is unclear because a personal pronoun, he, she, it, or they, can be link to some referring expression. For example, Denny has friendly parents. He also has a brother. $\underline{\mathrm{He}}$ is loved by his parents. Based on the sentence, the reader will be confused to determine personal pronoun he will refer to Denny or Denny's brother. Ambiguity brings not specific communicational effect. The sentence may be structural in a case of word order but it may lead the readers to have more than one interpretation.

\section{Discussion}

\subsection{Essay Writing}

According to Oshima and Hogue (1991:100), "an essay is a several paragraphs long writing instead of just one or two paragraphs and written about one topic, just as a paragraph is. However, a topic of essay is too complex to discuss in a paragraph. Therefore, it must be divided into several paragraphs, one each major point. Then the tie must be all the paragraphs together with adding an introduction and conclusion "in line with the opinion of Djuharie and Suherli in Khuzaemah and Herawati (2017:150) say that essay is a part (piece) of writing, but can also be interpreted as a short essay, intact bouquet. Therefore, the essay is one 
type of writing that is often used as a test tool to measure one's intelligence. A knowledgeable person will be able to convey his ideas in a coherent, logical and interesting manner.

According to Oshima and Hogue (1991:101), there are three important parts in writing essay, such as:

\section{a. An Introductory Paragraph}

The introductory paragraph consists of two parts, the first is a few general statements about the topic of interest to the reader and the second is a thesis statement that is to deliver important or specific parts of the topic or plan that will be written. the thesis in writing an essay is the same as the topic or main sentence in writing a paragraph. There are four purposes in the introductory paragraph, they are (1) Submit the topic in the essay, (2) Provide a general description of the topic, (3) Declare all plans in the essay, and (4) attract the reader's interest about the topic.

\section{b. Body}

The body consists of one or more paragraphs. Each paragraph develops a subdivision of the topic, so the number of paragraphs in the body will vary with the number of subtopics. The body is the longest part of the essay and can contain as many paragraphs as necessary to support the controlling ideas of the thesis statement. Each body paragraph has a topic sentence and several supporting sentences. It may or may not have a concluding sentence. Each body paragraph supports the thesis statement.

\section{c. Conclusion}

The concluding paragraph is the last paragraph of an essay. It has three purposes: It signals the end of the essay, it reminds the reader of your main points, and it leaves the reader with your final thoughts on the topic. The first part of the concluding paragraph summarizes the main points or repeats the thesis statement in different words. It may require one or more than one sentence. In the second part, you may add a final comment.

There are four main stages in teaching writing process: prewriting, planning, writing and revising drafts, and final writing (Oshima, 1991:3-12). The stages are described as follows.

1. Pre writing

The first stage is planning (prewriting). Prewriting is the stage where to generate ideas for what to be written. The following activities provide the learning experiences for students at these stages:

a. Brainstorming

Brainstorming is the prewriting step to generate ideas. Many teachers and learners seem that this activity is unnecessary at first, after doing them a few times, they will realize their usefulness. Brainstorm for 
ideas can get students writing is more quickly and give more time to the next stages of writing.

b. Listing

Listing is brainstorming technique in which the students think about the writing topic and quickly make a list of whatever words or phrases come into their mind. The teacher may guide the students to produce as many ideas as possible in a short time, and find specific focus for the topic.

\section{c. Freewriting}

Freewriting is a brainstorming activity in which the students write freely about the topic. While the students are writing, another idea will come. As with listing, the purpose of freewriting is to generate as many ideas as possible and to write them down without worrying about appropriateness, grammar, vocabulary, content, mechanics, and organization. The students can continue freewriting as long as he or she can generate ideas related to the topic. Then, after completing that task, the students can reread it and develop certain points, add some more ideas, or even delete others. The student can do this freewriting activity several times until they are satisfied what they have written. d. Clustering is another brainstorming activity can be used to generate ideas. The students may write the writing topic in the center of paper and draw a circle around it. Then, write every idea comes into the circle around the core. Think it again, and make more circles of ideas around them.

\section{Planning}

The second stage is planning. In this stage, the students are guided to choose topics and narrowed them, and the students generate their ides by brainstorming. The students are guided to organize the ideas have been generated by brainstorming into an outline.

The first step toward making an outline is to divide the ideas in the list further into sub lists and cross out any items that do not belong or that are not useable. The second step is writing the topic sentence. Finally, the students can write a topic sentence. The topic sentence is the most general sentence in a paragraph, and it expresses the central focus of the paragraph. The third step is writing outline. In outline, the students write down the main points and sub points in the order in which they play to write about of. By doing these three steps, writers are expected 
to produce writing that will be able to explain something to the readers.

3. Writing and Revising Drafts

The third stage is writing and revising drafts. In this stage, the students are guided to write and revise several drafts until they have final writing. The steps of this stage are writing the first rough draft from the outline, revising the content and organization, proof reading the second draft to check of grammar, sentence structure, spelling, punctuation, and vocabulary.

4. Final Writing

After passed the three previous stages, the students have finished their writing task. They have their final writing. The teacher will expect to be written neatly and legibly. The students must be sure that they make all the corrections that they noted on their draft.

\subsection{Concept of Ambiguity}

The accuracy of a text or paragraph is determined by the sentences which refer to the words structure that grammatical and structural. However, words structure and sentence structure can lead to be ambiguous even though they are grammatically correct. It is due to lexical or grammatical ambiguity. People may have the different interpretation due to the ambiguous words, phrase, and sentences. A sentence is said to be ambiguous whenever it can be associated with two or more different meanings.
According to Pateda (2010:201) ambiguity occurs when a person hears a speech or reads a text and then various interpretations appear. From the statements, it can be concluded ambiguous word (s), phrase (s), and sentence (s) have more than one interpretation. To figure out the exact interpretation or exact meaning of the words and sentences, they need the specific context. Ambiguity can be found in writing in everyday life, such as in a text, articles, and others.

Ambiguity is an inevitable problem. Ambiguity appears in spoken or written language. Written language (in this case is student text) has more complex grammars and does not use pauses, stress, hesitations, tone of voices, slides and intonations rather than spoken language. That is why teachers sometimes find their self difficult in understanding the message in student text because it can be interpreted in more than one meaning. This phenomenon is called as ambiguity. According to Kreidler (2002:11), a sentence that has two meanings is called ambiguous. The linguistic unit when associated with more than one meaning would then be ambiguous (Khoshkhabar \& Iraji, 2015:1020). “An expression is said to be ambiguous when more than one interpretation can be assigned to it" (Leech in Khoshkhabar \& Iraji, 2015:1021). Therefore, ambiguity can arise in a variety of ways. Ullmann in 
Pateda (2010:201) says, "Ambiguity is a linguistic condition that can arise in various ways."

Ambiguity is a phenomenon related to meaning. Sometimes the message (meaning) gotten from speaker or writer can cause confusion to the listener or reader, and it is also concerned to convey the message to others. Because the meaning contained in a word, phrase, sentence or text can be interpreted differently by others. So, meaning is a difficult term to explain. This is in line with Pateda (2010:9) says that the term meaning is a confusing word. However, he also said that although meaning is a confusing term, it actually meaning closer to the words. On the other hand, Ogden and Richards in Pateda (2010:82-83) concludes that: The meaning is an intrinsic vocabulary, a connection with other unique objects which cannot be analyzed, another word about a word contained in a dictionary, a word connotation, an essence, an activity that is projected into an object, an event in question and a desire, The place of things in a system, the practical consequences of an object in the interior for the foreseeable future, the theoretical consequences contained in a question, and the emotions generated by something.

There are several types of meaning. Yule (1996:114) distinguishes meanings into two types: conceptual and associative meanings. Conceptual meaning is a meaning that includes the basics, in which the essential component of meaning is conveyed by the use of the word literally. Some of the basic components of a word like needle in English might include 'thin, sharp, steel instrument'. These components would be part of the conceptual meaning of needle. Whereas, associative meaning is meaning that relate to the feeling of word expression through feelings. Different people might have different associations or connotations attached to a word like needle. They might associate it with 'pain', or 'illness', or 'blood', or 'drugs', or 'thread', or 'knitting', or 'hard to find', and these associations may differ from one person to the next.

Based on the explanation above, it can be concluded that the meaning is the purpose of the speaker or the writer delivered in the form of words or sentences. Therefore, when a word or sentence conveyed by a speaker or writer can be interpreted in more than one meaning will cause ambiguity.

\subsection{Types of Ambiguity}

There are several types of ambiguity. The following are the kinds of ambiguity according to some experts. First, according to Ullmann in Pateda (2010:202-205) the ambiguity is divided into three types: phonological ambiguity, lexical ambiguity, and grammatical ambiguity. The 
phonological ambiguity or ambiguity of the phonetic level is the ambiguity arising from the rapid mixing of the sounds of the language, so that there is doubt about the sound of the language heard from the speaker. For example:

I scream (I skri:m) or Ice cream (ais kri:m). When the hearers hear the utterance above, they may have the different interpretation whether 'I scream' refers to the action 'scream' or 'ice cream' refers to the kinds of drink.

Lexical ambiguity is the ambiguity caused by a word that contains more than one meaning or different words with the same form. Then this ambiguity can be seen in two ways, namely polysemy and homonymy. Polysemy is a phenomenon in which a single word can be associated to several different but related meanings. Homonymy is a phenomenon where the words are different but have the same form. For example:

Experts warn the current global financial turmoil may take a bigger toll on emerging Asia.

The word 'toll' in the sentence above may be interpreted into different ways since the word 'toll' has many interpretations. The readers may interpret the sentence into two interpretations. (1) Experts warn the current global financial turmoil may need or require a bigger payment on emerging Asia. In the first interpretation, toll is interpreted as payment. (2) Experts warn the current global financial turmoil may cause a bigger loss on emerging Asia. In the second interpretation, toll is interpreted as loss.

The grammatical ambiguity or ambiguity of the grammatical level is the ambiguity that arises in a group of words or sentences. Grammatical ambiguity is caused by several factors. According to Ullmann in Pateda (2010:204) there are three possible aspects which can be seen in ambiguity at this level, namely: (i) the possibility of ambiguity due to grammatical word formation (prefix and suffix), (ii) the possibility of an ambiguity due to a similar phrase (equivocal phrasing), and (iii) the possibility of an ambiguity arising in the context (the person or situation). For example:

Indonesian women and children are trafficked overseas for sexual and labor exploitation.

The sentence above may be interpreted into different ways. The readers may be confused in modifying the word 'Indonesian', whether it modifies the word 'women' only or 'children' also. However, the readers may interpret the sentence into two interpretations. First interpretation: 


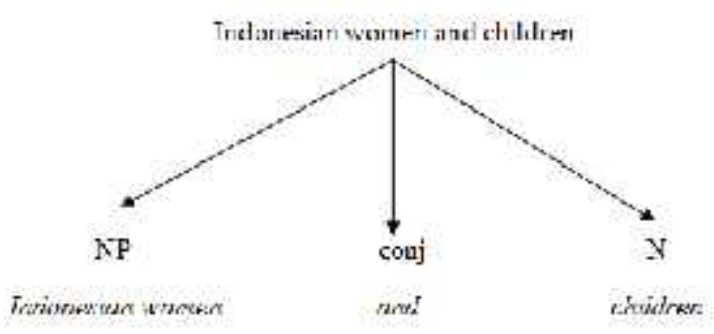

Picture 1. First Interpretation of Grammatical Ambiguity

Based on the picture above, it can be interpreted: Women from Indonesia and children are trafficked overseas for sexual and labor exploitation. Then, the picture below shows the second interpretation.

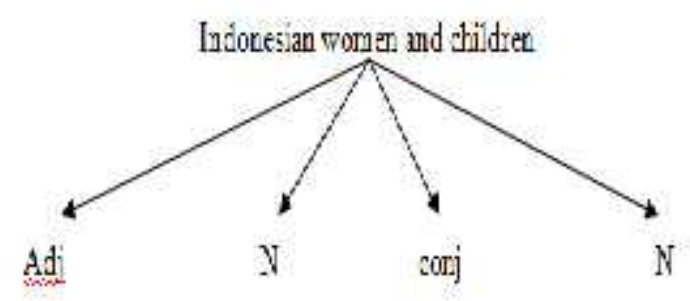

Picture 2. Second Interpretation of Grammatical Ambiguity

Based on the picture above, it can be interpreted: Indonesian women and Indonesian children are trafficked overseas for sexual and labor exploitation.

Second, according to Kreidler (2002:55, 151, and 169) there are three types of ambiguity, they are: lexical ambiguity, referential ambiguity, and syntactic ambiguity. Lexical ambiguity is the ambiguity caused by lexeme. Lexical ambiguity occurs when the use of a word has two meanings. Referential ambiguity or misunderstanding can occur when a sender of a message (speaker or writer) has one referent in mind for a definite expression, and the recipient is thinking of a different referent. Such phenomena must have been experienced (Kreidler, 2002:151).

Referential ambiguity can occur when: (i) an indefinite referring expression may be specific or not. For example, I wanted to buy a newspaper. Here a newspaper may refer to a specific newspaper or some newspaper, any newspaper. (ii) Anaphora is unclear because a personal pronoun, he, she, it or they, can be linked to either of two referring expressions. For example, Jack told Ralph that a visitor was waiting for him. (iii) The pronoun you is used generically or specifically. For example, if you want to get ahead, you have to work hard. Is you the addressee or is this sentence a general platitude? (iv) A noun phrase with every can have distributed reference or collected reference. For example, I'm buying a drink for everybody here.

The syntactic ambiguity arises when there are two or more possible meanings in a sentence. Later, Kreidler (2002:169) divides the syntactic ambiguity into two types: surface structure ambiguity and deep structure ambiguity. Surface structure ambiguity arises when words can be combined together in various possible constructions. Some examples of causes of surface structure ambiguity: Constructions containing the coordinators 
"and" and "or". For example, John and Mary or Pat will go. It can be interpreted into [John] and [Mary or Pat], [John and Mary] or [Pat]. (ii) A coordinate head with one modifier. For example, the only people left were old men and women. It can be interpreted into [old men] and [women], old [men and women]. A head with a coordinate modifier, a head with an inner modifier and an outer modifier, a complement and modifier or two complements, certain function words, including not, have possible differences in scope. Deep structure ambiguity arises when a single word sequence may have two or more interpretations. Some examples of causes of deep structure ambiguity: (i) Gerund + object or participle modifying a noun. For example, Overtaking cars on the main road can be dangerous. It can be interpreted into Overtaking cars is dangerous or Cars overtaking are dangerous. (ii) Adjective + infinitive, tied to subject or to complement. For example, the chicken is too hot to eat. It can be interpreted into too hot to eat anything or too hot for anybody to eat it. (iii) Ellipsis in comparative constructions. For example, $I$ like Mary better than Joan. It can be interpreted into better than I like Joan or better than Joan likes Mary.

Finally, according to Khoshkhabar \& Iraji (2015:1022-1025) the ambiguities are grouped into five types, namely: lexical ambiguity, syntactic ambiguity, logical ambiguity, referential ambiguity, and contextual ambiguity. Lexical ambiguity can occur in five ways, namely due to polysemy, homonymy, hyponym, homogrhapy, and idiomatic/figurative. Syntactic ambiguity is divided into two classifications, group ambiguity and ambiguity structural. Group ambiguity can originate from epenthesis, appositive, and conjunction. Structural ambiguity caused by the existence of ellipsis (ellipsis of pronoun, ellipsis of verb, ellipsis of genitive), structural disagreement, and punctuation.

Logical ambiguity is ambiguity that shows a clear contradiction. Alizadeh in Khoshkhabar \& Iraji (2015:1024) states, logical ambiguity seems irrelevant in the meaning of a semantic point of view, but can be easily interpreted on pragmatics. Referential ambiguity can occur when the listener or reader think different referent from the speaker or writer. Contextual ambiguity is the ambiguity caused by the context conditions allowing the different meanings of the word. Therefore, the word itself is not ambiguous, but the context that causes the word to be used becomes ambiguous (Alizadeh in Khoshkhabar \& Iraji, 2015:1025).

\section{Conclusion}

Writing is one of the skills in English that should be mastered by the students. 
Generally, writing is a way in sending the message from the writer to the reader. To write appropriately, it is needed for the students to master other English components, such as grammar, vocabulary, and spelling and punctuation. They must be able to organize the ideas to construct the sentences appropriately. Writing is considered as a productive skill, it aims at assisting students in expressing their written idea. an essay is a several paragraphs long writing instead of just one or two paragraphs and written about one topic, just as a paragraph is. However, a topic of essay is too complex to discuss in a paragraph. Therefore, it must be divided into several paragraphs, one each major point. Then the tie must be all the paragraphs together with adding an introduction and conclusion. There are three important parts in writing essay, such as: introduction, body, and conclusion.

Ambiguity is a linguistic condition that can arise in various ways. It is a phenomenon related to meaning. Sometimes the message (meaning) gotten from speaker or writer can cause confusion to the listener or reader, and it is also concerned to convey the message to others. Because the meaning contained in a word, phrase, sentence or text can be interpreted differently by others. ambiguity is divided into three types: phonological ambiguity, lexical ambiguity, and grammatical ambiguity. The phonological ambiguity or ambiguity of the phonetic level is the ambiguity arising from the rapid mixing of the sounds of the language, so that there is doubt about the sound of the language heard from the speaker. Lexical ambiguity is the ambiguity caused by a word that contains more than one meaning or different words with the same form. Then this ambiguity can be seen in two ways, namely polysemy and homonymy. Polysemy is a phenomenon in which a single word can be associated to several different but related meanings. Homonymy is a phenomenon where the words are different but have the same form. The grammatical ambiguity or ambiguity of the grammatical level is the ambiguity that arises in a group of words or sentences.

\section{References}

Kreidler, W. Charles. 2002. Introducing English Semantics. London \& New York: Taylor and Francis Group.

Khoshkhabar, G. Shahizad \& Iraji, Maryam. 2015. The Study of Ambiguity in social context of Iranian newspapers. International Journal of Advanced Research (2015), Volume 3, Issue 8, $1020-1027$. 
Khuzaemah, Emah dam Herawati, Lilik. 2017. Pembelajaran Menulis Esai Menggunakan Model CIRC Berbasis Life Skills. Cirebon: IAIN Syekh Nurjati.

Oshima, Alice. 1991. Writing Academic English. USA: Addision-Wasley Publishing Company.

Pateda, Mansoer. 2010. Semantik Leksikal. Jakarta: Rineka Cipta.

Weisman, Herman. M. 2007. Basic Technical Writing. Ohio: Charless E. Meririll

Yule, George. 1996. Semantics. New York: Cambridge University Press. 